\title{
KEADAAN HYGIENE SANITASI PEMINDANGAN IKAN DI SENTRA PEMINDANGAN IKAN DESA KUSAMBA KECAMATAN DAWAN KABUPATEN KLUNGKUNG TAHUN 2017
}

\author{
I Gusti Agung Ari Suci', I Nyoman Gede Suyasa ${ }^{2}$
}

\begin{abstract}
Fish is one of the most useful food for life, because it provides a relatively high protein. Salted Fish Center in Kusamba have a large production of fish product but the process still traditional and has never been examinated of sanitation and hygiene condition. The purpose of this reaserch is to know sanitation and hygiene condition of salted fish such as hygiene of employees, location and building, sanitation facilities, fish processing and equipment sanitation. Type of the research is descriptive with cross sectional approach. The sample on this research is 43 block of salted fish and all employee in there. Based on hygiene of employee assessment, obtained $17 \%$ is unqualified. Based on location and building assessment, obtained $30 \%$ is unqualified. Based on sanitation facilities assessment, obtained $26 \%$ is unqualified. Based on fish processing assessment, obtained $100 \%$ is qualified. and based on equipment sanitation obtained $28 \%$ is unqualified. The conclution is sanitation and hygiene condition of salted fish in Salted Fish Center is qualified.
\end{abstract}

Keyword: hygiene; sanitation; fish processing.

Provinsi Bali adalah salah bangunan pemindangan yang satu provinsi dengan pertumbuhan kotor/kurang bersih, belum konsumsi ikan terbesar yaitu 13,69 optimalnya fasilitas sanitasi, sampah $\%$. Bali memiliki 954 unit usaha pengolahan ikan dimana $70 \%$ merupakan usaha pemindangan. yang dihasilkan dari kegiatan pemindangan yang tidak memiliki tempat pembuangan khusus serta alat Salah satu pusat pemindangan ikan berada di Desa Kusamba Klungkung penanganan ikan yang kurang bersih. Produksi ikan pindang di Sentra yang dikenal dengan nama Sentra Pemindangan Ikan Kusamba.

Berdasarkan observasi awal, keadaan hygiene sanitasi di tempat pemindangan masih kurang diperhatikan seperti pekerja/karyawan yang tidak Pemindangan Ikan Desa Kusamba mencapai 4855,129 ton per tahun. Berdasarkan data tersebut diketahui bahwa Sentra Pemindangan Ikan Desa Kusamba memiliki produksi ikan pindang yang besar namun memakai alat pelindung diri, keadaan proses pemindangan masih tradisional dan keadaan hygiene 
sanitasi tempat pemindangan kurang diperhatikan serta belum

Penelitian ini bertujuan untuk mengetahui keadaan hygiene sanitasi pemindangan ikan di Sentra Pemindangan Ikan Desa Kusamba, Kecamatan Dawan, Kabupaten Klungkung yang terdiri dari penilaian hygiene karyawan pemindangan ikan, lokasi dan bangunan pemindangan ikan, proses pengolahan ikan pindang dan sanitasi peralatan pemindangan ikan yang kemudian dibandingkan dengan Keputusan Menteri Kelautan dan Perikanan Republik Indonesia Nomor 52A/KEPMEN-KP/2013 tentang Persyaratan Jaminan Mutu dan Keamanan Hasil Perikanan Pada Proses Produksi, Pengolahan dan Distribusi.

\section{METODE}

Dalam penelitian ini menggunakan jenis penelitian deskriptif dengan pendekatan cross sectional dengan mendeskripsikan keadaan hygiene sanitasi Pemindangan Ikan di Sentra Pemindangan Ikan yang terdiri dari variabel hygiene karyawan, lokasi dan bangunan, fasilitas sanitasi, pernah dilakukan penilaian hygiene sanitasi.

proses pengolahan ikan pindang dan sanitasi peralatan tanpa membandingkan variabel-variabel tersebut dan penilaian dilakukan sekali pada waktu tertentu. Penelitian dilakukan di Sentra Pemindangan Ikan Desa Kusamba pada Bulan Pebruari sampai dengan Bulan Juni 2017. Populasi dalam penelitian ini adalah 77 blok/bangsal pemindangan dan seluruh karyawan didalamnya yang kemudian diambil sampel sebanyak 43 blok/bangsal pemindangan dan seluruh karyawan yang bekerja di masing-masing blok dengan teknik pengambilan sampel acak sederhana (simple random sampling). Analisis data yang digunakan dalam penelitian ini adalah analisis univariat yang bertujuan untuk mendeskripsikan karakteristik setiap variabel penelitian yang kemudian dibandingkan dengan kategori. 
HASIL DAN PEMBAHASAN

1. Hygiene

Karyawan

Pemindangan Ikan

Penjamah makanan adalah orang yang berhubungan langsung dengan makanan dan peralatan mulai dari tahap persiapan, pembersihan, pengolahan, pengangkutan sampai dengan penyajian makanan(1). Berdasarkan karakteristik responden, karyawan pemindangan ikan $98 \%$ berjenis kelamin perempuan dengan usia 40 tahun - 49 tahun sebanyak 54 \% dan masa kerja 11 tahun - 20 tahun sebanyak $59 \%$. Tingkat pendidikan karyawan pemindang di Sentra Pemindangan Ikan Desa Kusamba $72 \%$ adalah tamatan SD. Berikut adalah hasil penilaian hygiene karyawan pemindangan ikan

Tabel 1

Hasil Penilaian Hygiene

Karyawan Pemindangan Ikan

Tahun 2017

\begin{tabular}{|c|c|c|}
\hline Kategori & $\begin{array}{c}\text { Frekwen } \\
\text { si (f) }\end{array}$ & $\begin{array}{l}\text { Persentase } \\
(\%)\end{array}$ \\
\hline $\begin{array}{c}\text { Memenuhi } \\
\text { Syarat }\end{array}$ & 49 & 83 \\
\hline $\begin{array}{c}\text { Tidak } \\
\text { Memenuhi } \\
\text { Syarat }\end{array}$ & 10 & 17 \\
\hline Jumlah & 59 & 100 \\
\hline
\end{tabular}

Berdasarkan tabel 1, didapatkan 10 sampel karyawan atau $17 \%$ tidak memenuhi syarat. Terdapat 15 orang pekerja atau $25 \%$ yang menderita penyakit mudah menular seperti batuk, pilek, diare serta penyakit lain yaitu demam dan gatal-gatal. Hal ini tidak sesuai dengan Keputusan Menteri Kelautan dan Perikanan Republik Indonesia Nomor 52A/KEPMEN-KP/2013 tentang Persyaratan jaminan Mutu dan Keamanan Hasil Perikanan Pada Proses Produksi, Pengolahan dan Distribusi, dimana salah satu syarat penjamah makanan adalah harus sehat dan tidak menderita penyakit menular atau menyebarkan kuman penyakit menular. Oleh karena itu disarankan kepada karyawan pemindang untuk melakukan pemeriksaan kesehatan yaitu pemeriksaan rectal swab.

Pemakaian alat pelindung diri juga kurang diterapkan, dimana terdapat diatas $90 \%$ karyawan yang tidak memakai APD seperti masker, sarung tangan dan celemek. Hal ini berbanding terbalik dengan penelitian Latudi(2) bahwa terdapat $91 \%$ responden/penjamah makanan yang menggunakan celemek dan 
pakaian yang bersih. Karyawan pemindang sebagian besar sudah menggunakan tutup kepala hal ini dibuktikan oleh karyawan yang tidak memakai tutup kepala hanya $17 \%$, dimana tutup kepala yang dipakai dalam bentuk topi dan kain penutup namun tidak dapat menutupi rambut secara sempurna. Hal ini hampir sama dengan penelitian yang dilakukan Budiyono(3) di Tembalang Kota Semarang dimana hanya $11,1 \%$ responden yang menggunakan tutup kepala karena terbiasa menggunakan kerudung, bukan tutup kepala untuk memasak. Penggunaan tutup kepala sebaiknya dapat menutupi rambut secara sempurna.

Pada saat pengolahan ikan pindang masih terdapat penjamah makanan/karyawan yang belum memiliki kebiasaan mencuci tangan setiap kali menangani makanan. Hasil penelitian ini sama dengan penelitian Latudi(2) terdapat banyaknya penjamah makanan tidak mencuci tangan sebelum menjamah/mengolah makanan yaitu sebanyak 78,57 \%. Berdasarkan penelitian Budiyono(3) tangan yang kotor merupakan sumber bakteri kontaminan, sehingga dapat beresiko menyebabkan kontaminasi pada produk pindang. Terdapat $22 \%$ penjamah makanan/karyawan yang menggunakan perhiasan cincin saat mengolah makanan. Pemakaian cincin/ aksesoris laiannya tidak diperbolehkan karena dapat menyebabkan kontaminasi pada produk makanan(1).

2. Lokasi Dan Bangunan Pemindangan Ikan

Lokasi dan bangunan adalah tempat yang digunakan untuk melakukan produksi/pengolahan makanan(1). Berikut adalah hasil penilaian lokasi dan bangunan pemindangan ikan

Tabel 2

Hasil Penilaian Lokasi dan Bangunan Pemindangan Ikan Tahun 2017

\begin{tabular}{|c|c|c|}
\hline Kategori & $\begin{array}{c}\text { Frekwensi } \\
\text { (f) }\end{array}$ & $\begin{array}{c}\text { Persent } \\
\text { ase (\%) }\end{array}$ \\
\hline $\begin{array}{c}\text { Memenuhi } \\
\text { Syarat }\end{array}$ & 30 & 70 \\
\hline $\begin{array}{c}\text { Tidak } \\
\text { Memenuhi } \\
\text { Syarat }\end{array}$ & 13 & 30 \\
\hline Jumlah & 43 & 100 \\
\hline
\end{tabular}

Berdasarkan tabel 2, didapatkan 13 sampel blok/bangsal pemindangan atau sebanyak 30\% termasuk kedalam kategori tidak memenuhi syarat. Berdasarkan 
observasi pada item bangunan didapatkan terdapat 32 blok/bangsal atau $74 \%$ memiliki ruang kerja/produksi dalam keadaan kotor. Tidak ada tempat khusus pengolahan ikan bersih maupun kotor sehingga beresiko menimbulkan kontaminasi.

Hal ini tidak sesuai dengan Keputusan Menteri Kelautan dan Perikanan Republik Indonesia Nomor 52A/KEPMEN-KP/2013 tentang Persyaratan Jaminan Mutu dan Keamanan Hasil Perikanan Pada Proses Produksi, Pengolahan dan Distribusi, dimana Unit Pengolahan Ikan harus mempunyai ruang kerja yang cukup untuk melakukan kegiatan dengan kondisi yang hygienis, harus mampu menghindari kontaminasi terhadap hasil perikanan, terpisah antara ruang penanganan hasil perikanan yang bersih dan ruang penanganan hasil perikanan kotor.

Terdapat 22 blok/bangsal atau $51 \%$ memiliki dinding dalam kondisi kotor dan tidak mudah dibersihkan walaupun sudah dikeramik. Hal ini sama dengan penelitian Susanto(4) di PHPT Muara Angke, Jakarta Utara, bahwa dinding-dinding pada bagian pengolahan ikan pindang PHPT Muara Angke kusam serta tidak mudah dibersihkan dan didesinfeksi. Terdapat $88 \%$ langit-langit pada blok/bangsal pemindangan dalam keadaan kotor dan sulit dibersihkan. Hal ini sama dengan penelitian Susanto(4) di PHPT Muara Angke, Jakarta Utara bahwa langit-langit pengolahan pindang UPT PHPT Muara Angke tidak dirancang untuk mencegah akumulasi kotoran, mengurangi kondensasi serta pengelupasan. Pencahayaan di dalam bangunan tidak memenuhi syarat karena $100 \%$ blok/bangsal memiliki pencahayaan diatas standar seperti yang disajikan pada tabel berikut :

Tabel 3

Hasil Pengukuran Pencahayaan Di Setiap Blok/Bangsal Pemindangan Ikan

\begin{tabular}{|c|c|c|c|}
\hline $\begin{array}{c}\text { N } \\
\text { o }\end{array}$ & $\begin{array}{c}\text { Pencahaya } \\
\text { an ( Lux ) }\end{array}$ & $\begin{array}{c}\text { Frekwe } \\
\text { nsi (f) }\end{array}$ & $\begin{array}{c}\text { Persenta } \\
\text { se (\%) }\end{array}$ \\
\hline 1 & $200-400$ & 16 & 37 \\
\hline 2 & $401-600$ & 18 & 42 \\
\hline 3 & $601-800$ & 8 & 21 \\
\hline \multicolumn{2}{|c|}{ Jumlah } & 43 & 100 \\
\hline
\end{tabular}

Sebanyak $42 \%$ memiliki pencahayaan 401 lux - 600 lux , hal ini diakibatkan karena ruangan terbuka sehingga menimbulkan silau akibat pantulan sinar matahari.berdasarkan penelitian 
Martiana(5), penerangan yang terlalu tinggi dan adanya kesilauan memberikan kondisi yang tidak ergonomis. Hal ini akan menyebabakan mata cepat lelah dan sering disertai sakit kepala.

3. Fasilitas Sanitasi Pemindangan Ikan

Fasilitas sanitasi adalah
sarana fisik bangunan dan
perlengkapannya digunakan untuk
memelihara kualitas lingkungan atau
mengendalikan faktor-faktor
lingkungan fisik yang dapat
merugikan manusia.

Tabel 4

Hasil Penilaian Fasilitas Sanitasi Pemindangan Ikan Tahun 2017

\begin{tabular}{|c|c|c|}
\hline Kategori & $\begin{array}{c}\text { Frekwensi } \\
\text { (f) }\end{array}$ & $\begin{array}{c}\text { Persentase } \\
(\%)\end{array}$ \\
\hline $\begin{array}{c}\text { Memenuhi } \\
\text { Syarat }\end{array}$ & 32 & 74 \\
\hline $\begin{array}{c}\text { Tidak } \\
\text { Memenuhi } \\
\text { Syarat }\end{array}$ & 11 & 26 \\
\hline Jumlah & 43 & 100 \\
\hline
\end{tabular}

Berdasarkan tabel 4, didapatkan 11 sampel blok/bangsal pemindangan atau $26 \%$ termasuk kedalam kategori tidak memenuhi syarat. Dimana $100 \%$ blok/bangsal pemindangan tidak melakukan pengolahan limbah cair karena tidak difungsikannya IPAL, serta saluran pembuangan limbah cair dalam keadaan terbuka dan air limbah mengalir dengan lambat. Pembuangan limbah hasil perikaan ke badan air akan menyebabkan pencemaran pada badan air mengingat limbah perikanan mengandung senyawa kimia berupa protein dan lemak. Menurut penelitian Sahubawa(6), protein dan lemak adalah senyawa yang mudah terurai, sehingga berpengaruh terhadap ketersediaan oksigen di badan air. Selain itu protein dan lemak memiliki potensi besar terhadap penyuburan perairan yang berlebihan (eutrification).

Terdapat $77 \%$ blok yang wadah limbah padatnya tidak terbuat dari bahan yang kuat melainkan dari anyaman bambu/keranjang. Hal ini tidak sesuai dengan Peraturan Menteri Perindustrian Republik Indonesia Nomor 75/MIND/PER/7/2010 dimana sistem pembuangan limbah didesain untuk mencegah agar tidak menjadi tempat berkumpulnya hama pengerat, serangga atau binatang lainnya sehingga tidak mencemari bahan pangan olahan maupun sumber air, wadah limbah terbuat dari bahan 
yang kuat dan tertutup rapat.

Keberadaan tempat pembuangan

yang dekat dengan tempat mengelola

makanan dengan kondisi tidak dalam

keadaan tertutup memungkinkan terjadinya kontaminasi Salmonella $s p$ (7).

Terdapat $98 \%$ pembuangan limbah di blok/bangsal pemindangan berhubungan langsung dengan pangan olahan/produk pindang karena tempat timbah padat letaknya disekitar tempat pemindangan serta saluran limbah cair yang terbuka. Sarana tempat cuci tangan sudah tersedia dalam jumlah yang cukup dan tersedia air yang cukup, namun sebanyak 29 blok atau $67 \%$ belum tersedia sabun cuci tangan. Menurut Peraturan Menteri Perindustrian Republik Indonesia Nomor 75/MIND/PER/7/2010, fasilitas cuci tangan diletakkan di depan pintu masuk ruangan pengolahan, dilengkapi dengan kran air mengalir dan sabun, dilengkapi dengan alat pengering tangan (handuk), dilengkapi dengan tempat sampah yang tertutup, tersedia dalam jumlah yang cukup.
4. Proses Pengolahan Ikan Pindang

Tabel 5

Hasil Penilaian Pengolahan Ikan Pindang

Tahun 2017

\begin{tabular}{|c|c|c|}
\hline Kategori & $\begin{array}{c}\text { Frekwensi } \\
\text { (f) }\end{array}$ & $\begin{array}{c}\text { Persentase } \\
(\%)\end{array}$ \\
\hline $\begin{array}{c}\text { Memenuhi } \\
\text { Syarat }\end{array}$ & 43 & 100 \\
\hline $\begin{array}{c}\text { Tidak } \\
\text { Memenuhi } \\
\text { Syarat }\end{array}$ & 0 & 0 \\
\hline Jumlah & 43 & 100 \\
\hline
\end{tabular}

Berdasarkan tabel 5, didapatkan sebanyak 43 sampel blok pemindangan atau $100 \%$ termasuk kedalam kategori memenuhi syarat. Namun terdapat 40 atau $93 \%$ blok/bangsal yang menyimpan produk pindang di besek yang tidak tertutup dan tidak terhindar dari binatang pengganggu seperti tikus dan lalat. Menurut $\operatorname{Budiman(8),~}$ pengemasan dan penyimpanan ikan pindang harus benar-benar diperhatikan agar mutu ikan pindang tidak menurun. Wadah ikan harus tertutup rapat agar tidak terkontaminasi oleh kotoran dari luar dan disimpan ditempat yang kering dan sejuk.

Berdasarkan penilaian didapatkan sebanyak $86 \%$ blok/bangsal yang tidak melindungi 
produk pindang dari sinar matahari dan panas. Sinar matahari dapat masuk langsung ke bangsal pemindangan karena kondisi bangsal yang terbuka. Di dalam bangsal juga terdapat proses perebusan sehingga suhu ruangan menjadi panas. Menurut Budiyono(3), menyimpan wadah ikan pindang di tempat yang panas atau lembab karena akan menyebabkan aktifitas bakteri dan enzim pembusuk kembali meningkat.

Terdapat $70 \%$ blok/bangsal didapatkan sampah di tempat penyimpanan produk pindang. Sampah tersebut berupa plastik pembungkus ikan dan serpihan kayu. Hal tersebut terjadi karena kondisi ruangan yang kotor dan tercampur sehingga ditemukan sampah. Oleh karena itu disarankan agar pemindang menjaga kebersihan ruangan produksi.

Pengangkutan pindang sudah dilakukan dengan alat pengangkut khusus yaitu untuk pedagang besar biasanya menggunakan mobil Cary dan untuk pedagang skala kecil menggunakan sepeda motor khusus, saat sebelum diangkut produk pindang ditutup dengan terpal. Pengangkutan produk pindang tanpa dikemas tidak dapat melindungi ikan pindang dari kontaminasi silang yang terjadi pada saat pengangkutan. Menurut Sujaya(9), cara mengangkut makanan harus memenuhi persayaratan sanitasi, misalnya apakah sarana pengangkutan memilki alat pendingin dan tertutup.

5. Sanitasi Peralatan Pemindangan Ikan

Peralatan adalah segala macam alat yang digunakan untuk mengolah dan menyajikan makanan (Keputusan Menteri Kesehatan republik Indonesia No.1098/MENKES/SK/VII/2003).

Berikut adalah hasil penilaian sanitasi peralatan pemindangan ikan

Tabel 6

Hasil Penilaian Sanitasi Peralatan Pemindangan Ikan

Tahun 2017

\begin{tabular}{|c|c|c|}
\hline Kategori & $\begin{array}{c}\text { Frekwensi } \\
(\mathrm{f})\end{array}$ & $\begin{array}{c}\text { Persentase } \\
(\%)\end{array}$ \\
\hline $\begin{array}{c}\text { Memenuhi } \\
\text { Syarat }\end{array}$ & 31 & 72 \\
\hline $\begin{array}{c}\text { Tidak } \\
\text { Memenuhi } \\
\text { Syarat }\end{array}$ & 12 & 28 \\
\hline Jumlah & 43 & 100 \\
\hline
\end{tabular}

Berdasarkan tabel 6, didapatkan empat sampel blok/bangsal pemindangan atau $28 \%$ termasuk kedalam kategori tidak 
memenuhi syarat. Hal ini terjadi karena terdapat berbagai permasalahan diantaranya terdapat $70 \%$ blok pemindangan yang menggunakan alat-alat yang berkarat pada panci perebusan ikan pindang dan besi untuk mengangkat pindang dari panci perebusan, serta pelaratan yang tidak mudah dibersihkan karena terjadi pengkaratan yang menimbulkan kerak. Terdapat $53 \%$ blok/bangsal yang memiliki alat yang menyebabkan kontaminasi pada hasil ikan. Hal ini terjadi karena pada saat proses perebusan terdapat beberapa alat perebusan yang berkarat dan berkerak sehingga berpotensi mengkontaminasi produk pindang. Terdapat $86 \%$ blok/bangsal yang tidak menyimpan peralatan pada tempat khusus karena tempat yang terbatas.

Hal ini tidak sesuai dengan Keputusan Menteri Kelautan dan Perikanan Republik Indonesia Nomor 52A/KEPMEN-KP/2013 tentang Persyaratan Jaminan Mutu dan Keamanan Hasil Perikanan Pada Proses Produksi, Pengolahan dan Distribusi, dimana persyaratan peralatan yang baik yaitu peralatan dan perlengkapan yang digunakan berhubungan langsung dengan ikan yang diolah, harus dirancang dan terbuat dari bahan tahan karat, tidak beracun, tidak menyerap air, mudah dibersihkan dan tidak menyebabkan kontaminasi terhadap hasil perikanan, peralatan dan perlengkapan harus ditata sedemikian rupa pada setiap tahapan proses untuk menjamin kelancaran pengelolahan, mencegah kontaminasi silang dan mudah dibersihkan.

Terdapat $53 \%$ blok/bangsal yang peralatannya tidak dicuci dengan sabun melaiankan hanya dengan air serta terdapat $72 \%$ blok/bangsal memiliki alat yang dalam kondisi kotor tidak terpisah dengan wadah produk/ besek yang bersih. Kondisi blok pemindangan yang kurang tertata menyebabkan alat untuk menangani ikan bersih dan pewadahan produk akhir seperti besek yang bersih disimpan menjadi satu. Hal ini tidak sesuai dengan Keputusan Menteri Kelautan dan Perikanan Republik Indonesia Nomor 52A/KEPMEN-KP/2013 tentang Persyaratan Jaminan Mutu dan Keamanan Hasil Perikanan Pada Proses Produksi, Pengolahan dan Distribusi, dimana peralatan dan 
perlengkapan harus ditata sedemikian rupa pada setiap tahapan proses, untuk menjamin kelancaran pengolahan dan mencegah kotaminasi silang.

\section{SIMPULAN DAN SARAN}

1. Simpulan

Keadaan hygiene sanitasi pemindangan ikan Desa Kusamba secara umum termasuk kedalam kategori memenuhi syarat. Namun masih ada beberapa sampel yang tidak memenuhi syarat antara lain pada penilaian hygiene karyawan yaitu sebayak $17 \%$, keadaan lokasi dan bangunan pemindangan ikan sebanyak $30 \%$, fasilitas sanitasi pemindangan ikan sebanyak $26 \%$ dan sanitasi peralatan pemindangan ikan sebanyak $28 \%$.

2. Saran

a. Kepada Pengelola Sentra Pemindangan Ikan Desa

Kusamba

Agar lebih menfasilitasi para pemindang berkaitan dengan penyediaan alat pelindung diri dan agar dapat mengoperasikan kembali Instalasi Pengelolaan Air Limbah (IPAL) dan meninjau kembali teknik pengolahan limbah yang digunakan.

b. Kepada Pemindang di Sentra

Pemindangan Ikan Desa

Kusamba

Agar melakukan cek kesehatan minimal enam bulan sekali di pusat pelayanan kesehatan serta melakukan pemeriksaan rectal swab untuk mengetahui apakah pekerja termasuk healty carrier atau tidak dan agar dapat lebih menerapkan prinsip hygiene sanitasi pengolahan makanan yang baik dalam hal ini adalah pengolahan ikan pindang.

c. Kepada Peneliti Berikutnya

Agar dapat melakukan penelitian mengenai iklim kerja di Sentra Pemindangan Ikan Desa Kusamba mengingat kondisi pekerja yang memiliki resiko terkena radiasi panas dari tungku perebusan sehingga berpengaruh menibulkan penyakit maupun gangguan emosional pekerja seperti stress. 


\section{DAFTAR PUSTAKA}

1. Sumantri. Kesehatan Lingkungan. Jakarta: Kencna Prenada Media Group; 2013.

2. Latudi. Aspek Hygiene Dan Sanitasi Makanan Di Pasar Jajan Kota Gorontalo Tahun 2012. Public Health. 2012;1.

3. Budiyono. Tingkat Pengetahuan Dan Praktik Penjamah Makanan Tentang Hygiene Dan Sanitasi Makanan Pada Warung Makan Di Tembalang Kota Semarang Tahun 2008. J Promosi Kesehat Indones. 2009;4.

4. Susanto K. Mempelajari Penerapan Sanitasi dan Mutu Keamanan Pengolahan Pindang Ikan Tongkol (IEuthynnus affinis) Studi Kasus Di Pengolahan Hasil Perikanan Tradisional (PHPT) Muara Angke Jakarta Utara. Bogor: IPB; 2010.
5. Martiana. Profil Kondisi Lingkungan Kerja Di Industri Pengolahan Udang. J Kesehat Lingkung. 2006;3.

6. Sahubawa. Analisis dan Prediksi Beban Pencemaran Limbah Cair Pabrik Pengalengan Ikan. J Mns dan Lingkung. 2011;18.

7. Wasisto. Gambaran Sanitasi Tempat Berdagang Warung Penyet Di Kecamatan Tembalang. J Kesehat Masy. 2016;4.

8. Budiman. Teknik

Pemindangan. Jakarta; 2004.

9. Sujaya I. Identifikasi Penyebab Diare di Kabupaten Karangasem. Kesehat Masy Nas. 2010;4:186-92. 